\title{
Ethnomedicinal uses and pharmacological activities of Croton megalobotrys Müll Arg: A systematic review
}

\author{
Alfred Maroyi \\ Medicinal Plants and Economic Development (MPED) Research Center, Department of Botany, University of Fort Hare, Private \\ Bag X1314, Alice 5700, South Africa \\ *For correspondence: Email: amaroyi@ufh.ac.za; Tel: $0027406022322 ;$ Fax: 0027866177642
}

\begin{abstract}
Purpose: To provide an overview of the ethnomedicinal uses and pharmacological activities of Croton megalobotrys as to understand its potential value and importance in primary health care systems of local communities throughout its distributional range.

Methods: The literature search for information on ethnomedicinal uses and pharmacological activities of C. megalobotrys was undertaken using databases such as Web of Science, BMC, Science Direct, Elsevier, Scopus, PubMed and Scielo. Other relevant literature sources included books, book chapters, websites, theses, conference papers and other scientific publications.

Results: Croton megalobotrys is an important herbal medicine in southern Africa used as an abortifacient and purgative,and as remedy for human immunodeficiency virus/acquired immunodeficiency syndrome (HIV/AIDS) opportunistic infections, malaria, muscle aches or pain, sexually transmitted infections (STIS) and skin infections. The chemical constituent of C. megalobotrys is mainly composed of alkaloids and cinnamate derivative isolated from the stem bark. The biological activities demonstrated include antibacterial, antiplasmodial, anti-HIV and radical scavenging activities. Conclusion: The historical traditional usage of C. megalobotrys as herbal medicine in southern Africa calls for detailed phytochemical and pharmacological properties of the species aimed at identifying the compounds responsible for its wide usage as an herbal medicine.
\end{abstract}

Keywords: Alkaloids, Croton megalobotrys, Ethnopharmacology, Primary health, Southern Africa

Tropical Journal of Pharmaceutical Research is indexed by Science Citation Index (SciSearch), Scopus, International Pharmaceutical Abstract, Chemical Abstracts, Embase, Index Copernicus, EBSCO, African Index Medicus, JournalSeek, Journal Citation Reports/Science Edition, Directory of Open Access Journals (DOAJ), African Journal Online, Bioline International, Open-J-Gate and Pharmacy Abstracts

\section{INTRODUCTION}

Medicinal plants play an important role in managing and treating human and animal diseases and ailments throughout the world. According to van Wyk et al [1], plants are an important primary source of most medicines in the world and they still continue to provide humans with new herbal medicines. It is within this context that the ethnomedicinal uses pharmacological activities of Croton megalobotrys Müll. Arg. were evaluated. Croton megalobotrys is a member of the Croton genus of the Euphorbiaceae family, comprising about 1300 species worldwide [2]. According to Salatino et al [2], several Croton species are widely used as traditional medicines in Africa, Asia and South America. Research by several authors [3-8] revealed that $C$. megalobotrys is an important medicinal plant used by both rural and urban communities throughout its native distributional range in tropical Africa. Croton megalobotrys is traded as medicinal plant in herbal medicine (muti) markets or shops in the Mpumalanga province in South Africa [9]. Research done by Tshisikhawe et al [10] showed that harvesting of stem bark of $C$. megalobotrys 
for medicinal purposes may threaten the survival of the species in the Limpopo province in South Africa where the species is harvested from the wild as herbal medicine. Therefore, this review is aimed at assessing if there is correlation between the ethnomedicinal uses of $C$. megalobotrys and the documented phytochemical and pharmacological properties of the species. It is hoped that this ethnomedicinal and pharmacological information will highlight the value and importance of $C$. megalobotrys as a potential source of a wide range of pharmaceutical products in southern Africa and will provide useful information to other researchers interested in the plant species.

\section{METHODS}

The literature search for information on ethnopharmacology and therapeutic value of $C$. megalobotrys (i.e., its ethnomedicinal uses, including other traditional uses, its botany, distribution, phytochemistry and pharmacological properties of the species) was performed from September 2016 to March 2017. Publications from all years included in databases such as BMC, Elsevier, PubMed, Scielo, Science Direct, Scopus and Web of Science were considered. Other literature sources were obtained from the library collections at the University of Fort Hare, Alice campus, South Africa, including scientific papers published in books, book chapters, international journals, theses, conference papers and other scientific publications. The keywords used in the search included "Croton megalobotrys", the synonym of the species "Croton gubouga S. Moore", and English names such as "fever bark", "fever bark tree", "feverberry", "fever-berry croton", "large fever-berry" and "lowveld croton". All articles that appeared to meet the selection criteria were retrieved, and this review draws heavily on the research results published in international journals (33), books (13), websites (four), book chapters, dissertations and theses (three each),conference reports and scientific reports from international organizations (one each). Most of the ethnomedinal uses data on $C$. megalobotrys have been collected from Zimbabwe, Zambia, South Africa, Namibia, Mozambique, Malawi and Botswana.

\section{RESULTS}

\section{Botanical profile of Croton megalobotrys}

The generic name "Croton" was derived from a Greek word "kroton" meaning thick, in reference to the thick and smooth seeds [11], a common feature of most Croton species which belong to the Crotonoideae subfamily of the
Euphorbiaceae family [12-14]. The specific name "megalobotrys" was derived from Greek words meaning "big bunch of grapes" in reference to the big bunches of fruits, characteristic of the species $[11,12,15,16]$. The synonym of $C$. megalobotrys is C. gubouga S. Moore [12-16]. Croton megalobotrys has been recorded in Botswana, Zimbabwe, Zambia, Malawi, South Africa, Mozambique and Namibia (Figure 1). Croton megalobotrys is common in semideciduous savannah, at medium to low altitudes on alluvial soils and usually a constituent of riverine and swamp fringe forest or thicket [1217].

Croton megalobotrys is a shrubby to mediumsized, densely leafy tree reaching $15 \mathrm{~m}$ tall [17] with a stem up to $60 \mathrm{~cm}$ in diameter [13]. The bark is pale grey, smooth at first with vertical lines of lenticels, becoming rough and fissured in older trees. The leaves are ovate, roughly triangular with silvery green hairs on the under surface, 3-19 cm long and 1-13 cm wide [13]. The flowers are pale cream to yellowish green in colour, with either only male or female flowers or mixed and then with male flowers in upper part and one to several female flowers at the base [17]. The fruit is a rounded to ellipsoid drupe covered with whitish short hairs.

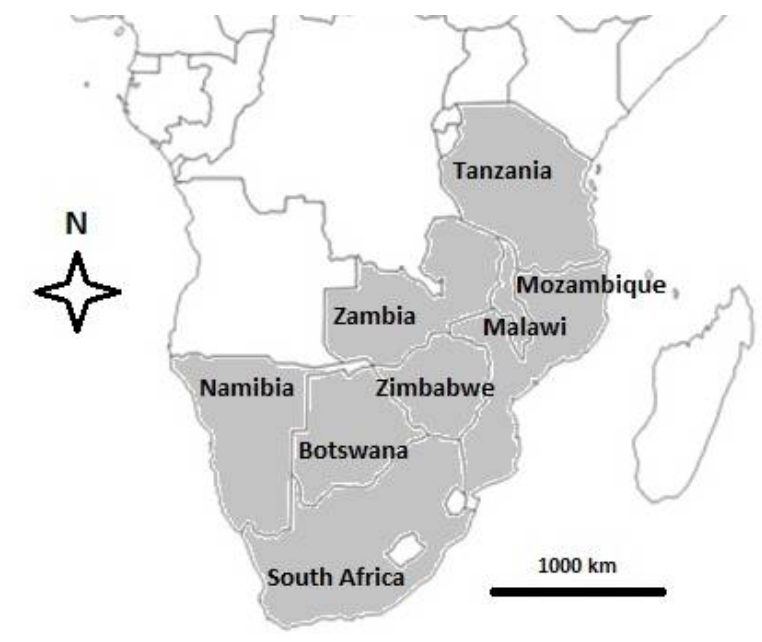

Figure 1: Distribution of Croton megalobotrys in southern Africa

Vernacular names and traditional uses of
Croton megalobotrys in southern Africa

There appear to be a direct correlation between the number of vernacular names and the traditional uses of $C$. megalobotrys in southern Africa (Figure 2). Literature search revealed that C. megalobotrys has no fewer than 62 vernacular names in southern Africa (Table 1), with South Africa having 21 vernacular names followed by Botswana with 20, Zimbabwe with eight and 
Namibia with six vernacular names (Table 1). Botswana has the highest number of uses of $C$. megalobotrys, 20 in total (Table 2) followed by South Africa with nine, Zimbabwe with seven and Malawi with six uses (Table 2). These findings support an observation made by Maroyi [18] that plant species characterized by several vernacular names implies that such species are useful to local people as theyrarely give vernacular names to plants that are not useful to them. This study revealed that $C$. megalobotrys has vernacular names and traditional uses in $87.5 \%$ of the countries where it is indigenous (Tables 1 and 2), with the exception of Tanzania where no vernacular names or traditional uses have been recorded. Croton megalobotrys is commonly referred to as "fever-berry" in $62.5 \%$ of the countries where it is indigenous, these include Zimbabwe, Botswana, Namibia, Malawi and South Africa (Table 1). Croton megalobotrys got such a common name mainly because the seeds and bark of the species have considerable reputation among local communities as remedy for fever or malaria [12-14,17,19]. Literature records indicate that on 30 September 1899, a medical officer, Dr John Maberly used bark and seeds of $C$. megalobotrys mixed with opium (Papaver somniferum L.) as remedy for malaria [20]. According to Coates Palgrave [17], C. megalobotrys bark and seeds are well known among local communities in southern Africa and early pioneers in malarial areas not only as a cure for fever but also as a prophylactic. Other common names which allude to the usage of $C$. megalobotrys as herbal medicine for fever or malaria include "fever bark", "fever bark tree", "fever-berry cotton", "large fever-berry" and "river fever-berry" (Table 1). The Afrikaans vernacular name "grootkoorsbessie" is a contraction of three words "groot", "koors" and "bessie" which translate to "large", "fever" and "berry" respectively in English, suggesting that the large fruits (berries) characteristic of the species are used against fever.

The bark, fruits, leaves, roots and seeds of $C$. megalobotrys are used as herbal medicines for 35 and two human and animal diseases respectively (Table 2). The bark or root infusion of $C$. megalobotrys is taken orally as an abortifacient and purgative or as herbal medicine for ascites also known as dropsy or pain in the alimentary canal in Malawi and Zimbabwe $[4,5,39]$. In Malawi, bark decoction of $C$. megalobotrys is applied on fresh wounds or cuts while leaf or root decoction is taken orally as remedy for headaches [7]. In Zimbabwe, root bark powder of $C$. megalobotrys is taken orally as remedy for female infertility [5] and bark or root decoction is taken orally as remedy for malaria [4]. Bark decoction of C. megalobotrys is also taken orally as herbal medicine for malaria in Mozambique [3] and Namibia [41]. In Botswana and South Africa, seeds or bark and root decoction of $C$. megalobotrys are taken orally as purgative $[3,6,17,24,28,32]$ or as herbal medicine for fever or malaria $[3,12,17,21,24,34]$ or berries are applied as poultices for skin infections or muscle aches or pain [24,35].

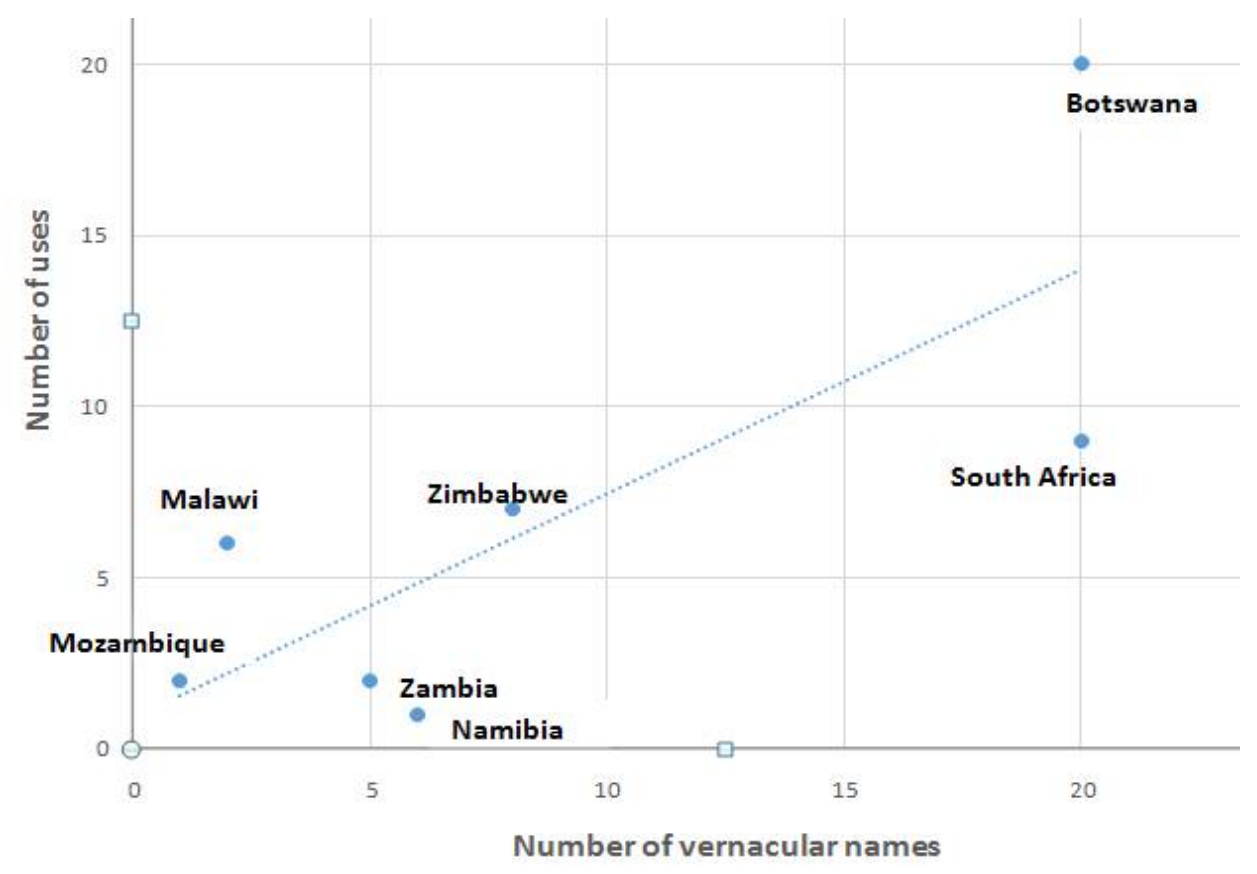

Figure 2: Relationship between the number of vernacular names and traditional uses of Croton megalobotrys in southern Africa 
Table 1: Vernacular names of Croton megalobotrys in southern Africa

\begin{tabular}{|c|c|c|}
\hline Vernacular names and ethnic group in brackets & Country & References \\
\hline $\begin{array}{l}\text { Fever-berry, large fever-berry, river fever-berry (English), mobwiti, moêpê, } \\
\text { mokungulu, moshoholo, moshoole, motlogatloga, motsêbê, motukatuka, } \\
\text { mukungulu, mutsebi, phofutsa, phokotsa, phufutsa, phukutsa, pokudza, } \\
\text { pukhutsa (Setswana), okayi (Seyei) }\end{array}$ & Botswana & {$[8,11,21-29]$} \\
\hline Mtutumuko (Chewa), fever-berry (English) & Malawi & {$[7,15]$} \\
\hline Chungué-chungué (Chindau) & Mozambique & [30] \\
\hline $\begin{array}{l}\text { Grootkoorsbessie (Afrikaans), fever-berry, large fever-berry (English), } \\
\text { mununkila, murongo, mutwatwa (Silozi) }\end{array}$ & Namibia & [31] \\
\hline $\begin{array}{l}\text { Grootkoorsbessie, koorsboom (Afrikaans), fever-bark, fever bark tree, fever- } \\
\text { berry, large fever-berry, lowveld croton (English), mohlokohloko (Pedi), moêpê, } \\
\text { mosôôlê, motsêbê, motshebe, motsibi, mutsebi, phukutsa (Setswana), lijaha } \\
\text { (Sotho), nxunguxungu, nxungwexungwe, shungweshungwe, xunguxungu } \\
\text { (Tsonga), muruthu (Venda) }\end{array}$ & South Africa & $\begin{array}{l}{[3,6,9,12,17,32} \\
-35]\end{array}$ \\
\hline $\begin{array}{l}\text { Muchape (Kore-kore), mtutu (Kunda), munanga (Kunda, Nsenga), mutua, } \\
\text { mutuatua (Tonga/Tokaleya/Lozi) }\end{array}$ & Zambia & [36-38] \\
\hline $\begin{array}{l}\text { Fever-berry, fever-berry croton (English), umtshape (Ndebele) mubvukuta, } \\
\text { muchape, mugubvuka, mushape (Shona), mutonga (Tonga) }\end{array}$ & Zimbabwe & {$[4,16,17,39,40]$} \\
\hline
\end{tabular}

The bark, leaf, root or seed decoction of $C$. megalobotrys is taken orally as herbal medicine for sexually transmitted infections (STIs) in Zambia [37] and other STIs such as gonorrhoea in Zambia [38] and venereal diseases in South Africa [6]. Research done by Mabogo [6] revealed that seed decoction of $C$. megalobotrys is taken orally as herbal medicine for kidney problems and purification of the blood. In Botswana, root infusion of $C$. megalobotrys is taken orally for fattening babies [11] and seed decoction of the species is taken orally as laxative [22]. Recently, research done by Tietjen et al [8] in Botswana revealed that $C$. megalobotrys is widely used to treat or manage human immunodeficiency virus/acquired immunodeficiency syndrome (HIV/AIDS) opportunistic infections such as diarrhoea, loss of appetite and stomach problems.

Croton megalobotrys is used as ethnoveterinary medicine by the resource-limited farmers in Botswana as an alternative to orthodox pharmaceuticals. Leaf decoction of $C$. megalobotrys is applied on lumpy skin [27] and bark or leaf decoction is also applied on animal sores or wounds [29]. Croton megalobotrys stem bark is widely used as a fish poison in Botswana $[21,23]$, Mozambique [3] and South Africa [3,42]. Croton megalobotrys also provides varied products throughout its distributional range and these include construction poles, timber and firewood. According to Mutakela [43], C. megalobotrys is an important source of timber and other non-woody plant products in rural areas of Botswana. In Botswana, $C$. megalobotrys is browsed by game and livestock [44] and its leaf decoction is used as a pesticide, usually sprayed on arable land to kill worms [29]. Research by Hamilton et al. [45], and Raman and Kandula [46] showed that $C$. megalobotrys is used as a stimulant by chacma baboons (Papio ursinus). Chacma baboons in South Africa are known to consume each day a little quantity of leaves of the species, which is not classified as the baboon's regular diet $[45,46]$. Consumption of $C$. megalobotrys is not directly related to any illness but for its stimulant activity [46]. Croton megalobotrys is planted as an ornamental and shade plant in rural areas of Botswana [29].

\section{DISCUSSION}

\section{Correlation between ethnomedicinal uses and pharmacological activities of $C$. megalobotrys}

Aligning the available ethnomedicinal information about $C$. megalobotrys in southern Africa, it appears that the species is most commonly used as anabortifacient, fish poison, purgative and as herbal medicine for the treatment and management of HIV/AIDS opportunistic infections, malaria and STIs (Figure 3). Several other Croton species including $C$. macrostachyus Hochst. ex Delile, C. megalocarpus Hutch. and C. sylvaticus Hochst. ex C. Krauss. are widely used as purgatives [48-50]. The seeds of $C$. tiglium L. are the sources of a commercially produced and marketed croton oil widely used as a purgative [2]. Croton megalobotrys also plays an important role in the treatment and management of HIV/AIDS and malaria which were classified among the top five killer diseases in Africa in 2012 by the World Health Organization. Research by Ramjee et al. [51] revealed that STIs are among the most prevalent infectious diseases worldwide and approximately 1 million women in Africa die yearly due to infection with HIV/AIDS and STIs. Whilst $C$. megalobotrys has proved to be useful over the centuries as herbal medicine for some of these important diseases in Africa, no meaningful 
phytochemical and pharmacological analyses exist in literature linking active principles of the species to its ethnomedicinal uses.

Apart from 4-hydroxyhygric acid isolated from the bark of $C$. megalobotrys by Goodson and Clewer [19] and a cinnamate derivative (E)tetratriacontyl-3-(4-hydroxy-3-methoxyphenyl)-2propenate (Figure 4) isolated from the chloroform fraction of the stem bark extract by Abosi and Majinda [52], little is known about the chemical constituents of the species. But genus Croton is known to have a wide range of chemical compounds including alkaloids, cardenolides, diterpenoids, flavonoids, saponins, mono and sesquiterpenoids [2,53]. The diterpenoids isolated from other species of the Croton genus are regarded as toxic irritants of the skin and mucosas [54] and they produce a burning sensation in the throat and mouth $[3,19]$.

Selowa et al [35] evaluated antibacterial activities of $n$-hexane, dichloromethane, ethyl acetate, acetone and methanol leaf powder extract of $C$. megalobotrys against Gram negative bacteria Enterococcus faecalis and Escherichia coli, and Gram positive bacteria Pseudomonas aeruginosa and Staphylococcus aureus using bioautograph and micro-dilution techniques.

Table 2: Traditional uses of Croton megalobotrys in southern Africa

\begin{tabular}{|c|c|c|c|}
\hline Use & Plant parts used & Country practiced & References \\
\hline Abortifacient & Bark or root decoction taken orally & Zimbabwe & {$[4,5,39]$} \\
\hline Ascites (dropsy) & Bark or root infusion taken orally & Malawi, Zimbabwe & {$[4,5]$} \\
\hline Cuts & $\begin{array}{l}\text { Bark decoction applied on affected body } \\
\text { part }\end{array}$ & Malawi & [7] \\
\hline Diarrhoea of HIV patients & Bark decoction taken orally & Botswana & [8] \\
\hline Fattening of babies & Root infusion taken orally & Botswana & [11] \\
\hline Female infertility & Root bark powder taken orally & Zimbabwe & [5] \\
\hline Fever & Seed taken orally & Botswana, South Africa & {$[24,34]$} \\
\hline Gonorrhoea & Leaf decoction taken orally & Zambia & [38] \\
\hline Headache & Leaf or root decoction taken orally & Malawi & [7] \\
\hline HIV/AIDS & Bark decoction taken orally & Botswana & [8] \\
\hline Kidneys problems & Seed decoction taken orally & South Africa & [6] \\
\hline Laxative & Seed decoction taken orally & Botswana & [22] \\
\hline Loss of appetite & Bark decoction taken orally & Botswana & [8] \\
\hline Malaria & Bark, root, seed decoction & $\begin{array}{l}\text { Botswana; Mozambique, } \\
\text { Namibia, South Africa, } \\
\text { Zimbabwe }\end{array}$ & {$[3,4,21,24,41$} \\
\hline Malaria & $\begin{array}{l}\text { Bark and seed mixed with opium } \\
\text { (Papaver somniferum L.) }\end{array}$ & South Africa & [20] \\
\hline Muscle aches or pain & $\begin{array}{l}\text { Berries applied on affected body part as } \\
\text { poultices }\end{array}$ & Botswana, South Africa & {$[24,35]$} \\
\hline Pain in alimentary canal & Bark powder taken orally & Malawi, Zimbabwe & [5] \\
\hline Purgative & Bark, root or seed decoction taken orally & $\begin{array}{l}\text { Botswana, Malawi, South } \\
\text { Africa, Zimbabwe }\end{array}$ & $\begin{array}{l}{[3-} \\
6,24,28,32]\end{array}$ \\
\hline Purification of blood & Seed decoction taken orally & South Africa & [6] \\
\hline $\begin{array}{l}\text { Sexually } \\
\text { infections (STIs) }\end{array}$ & Bark or root decoction taken orally & Zambia & {$[37,47]$} \\
\hline Skin infections & $\begin{array}{l}\text { Berries applied as poultices on affected } \\
\text { body part }\end{array}$ & Botswana, South Africa & {$[24,35]$} \\
\hline Stomach problems & Bark decoction taken orally & Botswana & [21] \\
\hline Venereal diseases & Seed decoction taken orally & South Africa & [6] \\
\hline \multicolumn{4}{|l|}{ Ethno-veterinary medicine } \\
\hline Lumpy skin & Leaf decoction applied on sores & Botswana & [27] \\
\hline Wounds & $\begin{array}{l}\text { Bark and leaf decoction applied on } \\
\text { wounds }\end{array}$ & Botswana & [29] \\
\hline \multicolumn{4}{|l|}{ Other uses } \\
\hline $\begin{array}{l}\text { Browse for game and } \\
\text { livestock }\end{array}$ & & Botswana & [44] \\
\hline Construction timber & & Botswana & {$[11,29]$} \\
\hline Fuel wood & & Botswana & [26] \\
\hline Fish poison & Bark, leaves and fruits used & $\begin{array}{l}\text { Botswana, Mozambique, } \\
\text { South Africa }\end{array}$ & {$[3,21,23,42]$} \\
\hline Kill worms in arable land & Leaf decoction sprayed on arable land & Botswana & [29] \\
\hline Ornamental & & Botswana & [22] \\
\hline Shade & & Botswana & [29] \\
\hline
\end{tabular}




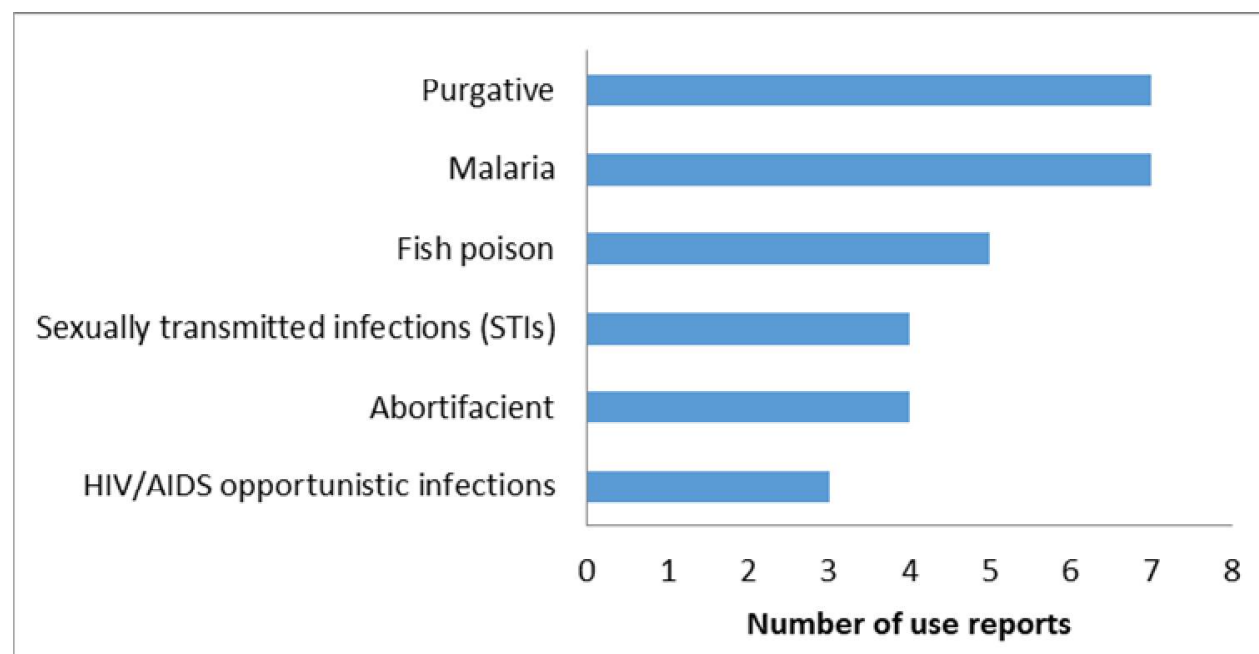

Figure 3: Main traditional applications of Croton megalobotrys in southern Africa. A traditional use is only counted once per publication

HO<smiles>CN1CCCC1C(=O)O</smiles>

4-hydroxyhygric acid<smiles>CCCCCOC(=O)/C=C/c1ccc(O)c(OC)c1</smiles>

(E)-tetratriacontyl-3-(4-hydroxy-3methoxyphenyl)-2-propenate

Figure 4: Chemical structures of compounds isolated from the bark of Croton megalobotrys

All extracts showed antibacterial activities, with the highest activity observed against Enterococcus faecalis with a minimal inhibitory concentration (MIC) value of $0.02 \mathrm{mg} / \mathrm{ml}$ [35]. These findings somehow support the species' antibacterial potential and its usefulness in its traditional usage as herbal medicine for diarrhoea [8], gonorrhoea [38], skin infections [24,35], STIs [37], stomach problems [8] and venereal diseases [6]. More research is recommended focusing on antibacterial activities of C. megalobotrysagainst known bacterial pathogens such as Neissseria gonorrhoeae which cause gonorrhoea, and other bacterial pathogens such as Shigella dysenterae, Shigella flexneri and Vibrio cholerae which cause gastrointestinal infections.

Abosi and Majinda [52] evaluated antiplasmodial activities of root, stem bark and leaf extracts of
C. megalobotrys in NMRI white albino mice infected with $1 \times 10^{7}$ Plasmodium berghei (ANKA) parasitized erythrocytes. The effects of the extracts were assessed on early infection, established infection and the residual effect of the extracts was also assessed using the Repository or Prophylactic test. The stem bark extract produced a suppressive effect of $74.5 \%$ in early infection and a residual inhibitory effect of $86.9 \%$. In an established infection, a mean survival time of 16.2 days was achieved although parasitaemia was not completely eliminated. Antiplasmodial activity was observed in in vitro test with $\mathrm{IC}_{50}$ values of $1.74 \pm .47 \mu \mathrm{g} / \mathrm{ml}$ and 3.78 $\pm 1.03 \mu \mathrm{g} / \mathrm{ml}$ for the hexane fraction of the stem bark extract against chloroquine sensitive (D6) and chloroquine-resistant (W2) strains of Plasmodium falciparum respectively [52]. The antiplasmodial activity demonstrated in this study support the folkloric use of $C$. megalobotrys for treating and managing malaria in southern Africa and also using the species as prophylactic medicine for malaria $[3,4,20,21,24]$. Previous research by Ndunda [53] revealed that over $70 \%$ of species belonging to the Croton genus reported in ethnomedicinal treatment of malaria and tested for antiplasmodial activities were found to be active, an indication of the potential of these species as antimalarial remedies. The preliminary radical scavenging evaluation carried out by Abosi and Majinda [52]using the chloroform fraction in qualitative 2,2-diphenyl-1picrylhydrazyl (DPPH) assay showed activity at a loading dose of $0.05 \mu \mathrm{g}$, thus exhibiting radical scavenging activity comparable to that of ascorbic acid. Collectively, data obtained by Abosi and Majinda [52] indicate that $C$. megalobotrys suppresses free radical formation, however, determining the exact mechanisms of action will require further investigations. 
Tietjen et al [8] evaluated the crude extracts of $C$. megalobotrys for in vitro cytotoxicity and inhibition of wild-type (NL4.3) and ARV-resistant HIV-1 replication in an immortalized GFPreporter $\mathrm{CD} 4_{+} \mathrm{T}$-cell line. The study by Tietjen et al [8] is based on the wide use of $C$. megalobotrys as herbal medicine for treating and managing HIV/AIDS in Botswana where in some cases the species is used concurrently with standard ARVs. Croton megalobotrys bark extracts inhibited HIV-1NL4.3 replication with dose-dependence and without concomitant cytotoxicity and inhibited HIV-1 replication by a maximum of $45 \%$ at concentrations as low as $0.05 \mathrm{mg} / \mathrm{ml}$. According to Tietjen et al [8],C. megalobotrys extracts did not interfere with antiviral activities of licensed ARVs when applied in combination and exhibited comparable efficacies against viruses harboring major resistance mutations to licensed protease, reverse-transcriptase, or integrase inhibitors. Based on these findings, C. megalobotrys can therefore, be administered in parallel with Western HIV/AIDS treatments in managing the effects of HIV/AIDS in Botswana, a disease that has become a devastating epidemic in subSaharan Africa [55].

\section{Toxicity evaluation}

A number of ethnobotanical studies have highlighted the toxicity of $C$. megalobotrys when used as herbal medicine. Croton megalobotrys is a well-known poisonous plant in South Africa $[32,56]$ and Zimbabwe $[4,5,40,57]$, although it is widely used as herbal medicine in both countries. According to Gelfand et al [5], taking of bark and root of C. megalobotrys has been reported to cause swelling of testicles in Zimbabwe. Mabogo [6] emphasized the need to follow traditional healers' dosage instructions when using $C$. megalobotrys as a purgative, since there is a possibility of fatal side effects. It is commonly recommended that an adult should take one or three quarters of a seed at a time [6]. Preliminary toxicity investigations showed that ground bark of C. megalobotrys caused purgation and emesis in dogs, but rabbits were less sensitive although in doses of $1 \mathrm{~g} / \mathrm{kg}$ of body weight induced diarrhoea [19]. In human beings, administration of $C$. megalobotrys bark causes intense burning sensation in the throat, salivation and slight nausea with slight laxative effect $[3,19]$. The toxicity effects of $C$. megalobotrys are attributed to toxic diterpenes which are characteristic of most species belonging to the Croton genus [58]. No detailed cytotoxicity or toxicity effects of $C$. megalobotrys have been undertaken recently, although it is clear that detailed toxicity studies for such a widely used medicinal plant in southern Africa are required.

\section{CONCLUSION}

The historical traditional usage of $C$. megalobotrys as herbal medicine in southern Africa calls for detailed phytochemical and pharmacological properties of the species aimed at identifying the compounds responsible for its wide usage as herbal medicine. At the present moment, there is not yet enough systematic data regarding phytochemistry, pharmacological properties and clinical research of $C$. megalobotrys extracts and compounds. There are very few to nil experimental studies, clinical research trials and target-organ toxicity studies involving C. megalobotrys extracts and its compounds that have been carried out so far. Given this background, it is quite difficult to correlate the ethnomedicinal uses of the species with the few phytochemical profiling and pharmacological evaluations that have been done so far. There is need therefore, to evaluate pharmacological properties of the species, as these may be directly related to the species ethnomedicinal uses. Detailed pharmacological studies will provide some insight into the therapeutic potential of $C$. megalobotrys. Since C. megalobotrys is classified as poisonous in southern Africa [4-6,32,40,56], there is need for a detailed toxicological assessment of the species using reliable analytical methods.

\section{DECLARATIONS}

\section{Acknowledgement}

Financial support of this work by the National Research Foundation (NRF) and Govan Mbeki Research and Development Centre (GMRDC), University of Fort Hare is gratefully acknowledged.

\section{Conflict of Interest}

No conflict of interest associated with this work.

\section{Contribution of Authors}

The authors declare that this work was done by the authors named in this article and all liabilities pertaining to claims relating to the content of this article will be borne by them.

\section{Open Access}

This is an Open Access article that uses a funding model which does not charge readers or their 
institutions for access and distributed under the terms of the Creative Commons Attribution License (http://creativecommons.org/licenses/by/ 4.0) and the Budapest Open Access Initiative (http://www.budapestopenaccessinitiative.org/rea d), which permit unrestricted use, distribution, and reproduction in any medium, provided the original work is properly credited.

\section{REFERENCES}

1. van Wyk B-E, van Oudtshoorn B, Gericke N. Medicinal plants of South Africa. Pretoria: Briza Publications; 2013; $p 336$

2. Salatino A, Salatino MLF, Negri G. Traditional uses, chemistry and pharmacology of Croton species (Euphorbiaceae). J Braz Chem Soc 2007; 18: 11-33.

3. Watt JM, Breyer-Brandwijk MG. The medicinal and poisonous plants of Southern and Eastern Africa. Livingstone, London; 1962; $p 1457$.

4. Nyazema NZ. Poisoning due to traditional remedies. The Centr Afr J Med 1984; 30: 80-83.

5. Gelfand M, Mavi S, Drummond RB, Ndemera B. The traditional medical practitioner in Zimbabwe: His principles of practice and pharmacopoeia. Mambo Press, Gweru; 1985; p 411.

6. Mabogo DEN. The ethnobotany of the Vhavenda. MSc dissertation, University of Pretoria, Pretoria; 1990; $p$ 260.

7. Pullanikkatil D, Palamuleni LG, Ruhiiga TM. Land use/land cover change and implications for ecosystems services in the Likangala River Catchment, Malawi. Phys Chem Earth, Parts A/B/C 2016; 93: 96-103.

8. Tietjen I, Gatonye $T$, Ngwenya BN, Namushe A, Simonambanga $S$, Muzila M, Mwimanzi $P$, Xiao J, Fedida D, Brumme ZL, Brockman MA, Andrae-Marobela K. Croton megalobotrys Müll Arg. and Vitex doniana (Sweet): Traditional medicinal plants in a three-step treatment regimen that inhibit in vitro replication of HIV1. J Ethnopharmacol 2016; 191: 331-340.

9. Botha J, Witkowski ETF, Shackleton CM. Factors influencing prices of medicinal plants traded in the Lowveld, South Africa. Int J Sustain Develop World Ecol 2007; 14: 450-469.

10. Tshisikhawe MP, MW van Rooyen, RB Bhat. An evaluation of the extent and threat of bark harvesting of medicinal plant species in the Venda Region, Limpopo Province, South Africa. Pyton: Int J Exp Bot 2012; 81: 89-100.

11. Hargreaves BJ. The spurges of Botswana. Botswana Notes Rec 1991; 23: 115-158.

12. Palmer E, Pitman P. Trees for southern Africa covering all known indigenous species in Republic of South Africa, South West Africa, Botswana, Lesotho and Swaziland. Cape Town: AA Balkema; 1972; $p 792$.

13. Smith AR. Euphorbaceae. In: Polhill RM (Ed.), Flora of tropical East Africa. Rotterdam: AA Balkema; 1987; pp. 20-391.
14. Radcliffe-Smith A. Euphorbiaceae. Flora Zamb 1996; 9: 288-289.

15. Hyde MA, Wursten BT, Ballings $P$, Coates Palgrave $M$. Flora of Malawi: Species information: Croton megalobotrys Müll. Arg.; 2017. Available on: http://www.malawiflora.com/speciesdata/species.php?sp ecies_id=134790, retrieved 15 March 2017.

16. Hyde MA, Wursten BT, Ballings $P$, Coates Palgrave $M$. Flora of Zimbabwe: Species information: Croton megalobotrys Müll. Arg.; 2017. Available on:http://www.zimbabweflora.co.zw/speciesdata/species .php?species_id=134790, retrieved 15 March 2017.

17. Coates Palgrave K. Trees of southern Africa. Cape Town, Struik Publishers; 2002; $p 1212$.

18. Maroyi A. Ximenia caffra Sond. (Ximeniaceae) in subSaharan Africa: A synthesis and review of its medicinal potential. J Ethnopharmacol 2016; 184: 81-100.

19. Goodson JA and Clewer HWB. Examination of the bark of Croton gubouga: Isolation of 4-hydroxyhygric acid. $J$ Chem Soc 1919; 115: 923.

20. Maberly J. The pharmacology of some South African plants. Lancet 1899; 157: 874.

21. Teichler GH. Notes on the Botswana pharmacopoeia. Botswana Not Rec 1971; 3: 8-11.

22. Hedberg I, Staugard F. Traditional medicinal plants in Botswana. Ipeleng, Gaborone; 1989. 324 p.

23. Parratt NT. The potential of non-timber forest products of Botswana. Botswana Not Rec 1996; 28: 203-218.

24. Bolten $C$. Healing knowledge and cultural practices in a modern Tswana village. BA Honours dissertation. Williams College, United States; 1998; $p 133$.

25. Setshogo MP, Venter F. Trees of Botswana: Names and distribution. Southern African Botanical Diversity Network Report No. 18. Pretoria; 2003; $p 162$.

26. Mmopelwa G, Blignaut JN, Hassan R. Direct use values of selected vegetation resources in the Okavango Delta Wetland. South Afr J Econ Manag Sci 2009; 12: 242255.

27. Gabalebatse M, Ngwenya BN, Teketay D, Kolawole $O D$. Ethno-veterinary practices amongst livestock farmers in Ngamiland district, Botswana. Afr J Tradit Complement Altern Med 2013; 10: 490-502.

28. Mothanka DMT, Nthoiwa GP. Ethnobotanical survey of medicinal plants of Tswapong north, in eastern Botswana: A case of plants from Mosweu and Seolwane villages. Europ J Med PI 2013; 3: 10-24.

29. Neelo J, Kashe K, Teketay D, Masamba W. Ethnobotanical survey of woody plants in Shorobe and Xobe villages, northwest region of Botswana. Ethnobot Res Appl 2015; 14: 367-379.

30. Conde $P$, Figueira R, Saraiva S, Catarino L, Romeiras $M$, Duarte MC. The Botanic Mission to Mozambique (19421948): contributions to the knowledge of the medicinal flora of Mozambique. História, Ciências, Saúde Manguinhos, Rio de Janeiro; 2014; vol 21, no 2, abr-jun.

31. Tree atlas of Namibia. Croton megalobotrys: murongo. 2017.

Available

on: 
http://treeatlas.biodiversity.org.na/viewspec.php?nr=182, retrieved 11 March 2017.

32. Liengme CA. Plants used by the Tsonga people of Gazankulu. Bothalia 1981; 13: 501-518.

33. Schmidt E, Lotter M, McCleland W. Trees and shrubs of Mpumalanga and Kruger National Park. Jacana Media, Johannesburg; 2002. $702 p$.

34. Venter F, Venter J-A. Making the most of indigenous trees. Briza Publications. Pretoria, South Africa; 2007. $368 p$.

35. Selowa SC, Shai LJ, Masoko P, Mokgotho MP, Magano $S R$. Antibacterial activity of extracts of three Croton species collected in Mpumalanga region in South Africa. Afr J Tradit Complement Altern Med. 2009; 30:7:98-103.

36. Astle WL, Phiri PSM, Prince SD. A dictionary of vernacular-scientific names of plants of the midLuangwa Valley, Zambia. Kirkia 1997; 16: 161-203.

37. Ndubani P, Höjer B. Traditional healers and the treatment of sexually transmitted illnesses in rural Zambia. J Ethnopharmacol 1999; 67: 15-25.

38. Chinsembu KC. Ethnobotanical study of plants used in the management of HIVIAIDS-related diseases in Livingstone, southern province, Zambia. EvidenceBased Complem Altern Med 2016; Vol 2016, Article ID 4238625.

39. Sewani-Rusike CR. Plants of Zimbabwe used as antifertility agents. Afr J Trad, Complement Altern Med 2010; 7: 253-257.

40. Maroyi A. Garden plants in Zimbabwe: Their ethnomedicinal uses and reported toxicity. Ethnobot Res Appl 2012; 10: 45-57.

41. Chinsembu KC. Plants as antimalarial agents in subSaharan Africa. Acta Tropica 2016; 152: 32-48.

42. Neuwinger HD. Plants used for poison fishing in tropical Africa. Toxicon 2004; 44: 417-430.

43. Mutakela PS. State of Forest Genetic Resources in Botswana. Prepared for the SADC Regional Workshop on Forest and Tree Genetic Resources, Arusha, Tanzania, 5-9 June 2000. Forest Genetic Resources Working Papers, Working Paper FGR/11E. Forest Resources Development Service, Forest Resources Division. FAO, Rome; 2001.

44. Rooke T, Danell K, Bergström R, Skarpe C, Hjältén J. Defensive traits of Savanna trees: The role of shoot exposure to browsers. Oikos 2004; 107: 161-171.
45. Hamilton iii WJ, Buskirk RE, Buskirk WH. Omnivory and utilization of food resources by chacma baboons, Papio ursinus. American Naturalist 1978; 112: 911-924.

46. Raman $R$, Kandula S. Zoopharmacognosy: Selfmedication in wild animals. Resonance 2008; 13:245.

47. Jumbe CBL, Bwalya SM, Husselman M. Contribution of dry forests to rural livelihoods and the national economy in Zambia. In Managing the Miombo woodlands of Southern Africa policies, incentives and options for the rural poor Technical Annexes (pp. 1-22). World Bank: Sustainable Development Department Environment and Natural Resources Management Unit Africa Region; 2008.

48. Burkill HM. The useful plants of West tropical Africa. London, Kew, Royal Botanic Gardens; 1985. 648 p.

49. Mazzanti G, Bolle P, Martinoli L, Piccinelli D, Grqurina I, Animati F, Mugne $Y$. Croton macrostachyus, a plant used in traditional medicine: purgative and inflammatory activity. J Ethnopharmacol 1987; 19: 213-219.

50. Lovett JC, Ruffo CK, Gereau RE. Field guide to the moist forest trees of Tanzania. London: Society for Environmental Exploration; 2006. 193 p.

51. Ramjee G, Abbai NS, Naidoo S. Women and sexually transmitted infections in Africa. Open J Obstetr Gynecol 2015; 5: 385-399.

52. Abosi AO, Majinda RRT. Anti-plasmodial and radical scavenging activities of Croton megalobotrys. Res Reviews J Pharmacog Phytoch 2015; 3: 73-78.

53. Ndunda B. Phytochemistry and bioactivity investigations of three Kenyan Croton species. PhD Thesis, University of Nairobi, Nairobi; 2014. $307 p$.

54. Bruneton J. Pharmacognosy, phytochemistry of medicinal plants. Lavoisler Publishing Co., Paris; 1995; $313 p$.

55. Maroyi A. Alternative medicines for HIVIAIDS in resource-poor settings: Insight from traditional medicines use in sub-Saharan Africa. Trop $J$ Pharmaceut Res 2014; 13: 1527-1536.

56. Bullock $A A$. South African poisonous plants. Kew Bull 1952; 7: 117-129.

57. Mavi S. Medicinal plants and their uses in Zimbabwe. In: Norman $H$, Snyman I, Cohen M (Eds.), Indigenous knowledge and its uses in Southern Africa. Human Sciences Research Council, Pretoria; 1996: 67-73.

58. Lewis WH, Elvin-Lewis MPF. Medical botany: Plants affecting man's health. Wiley-Interscience, New York; 1977; $p 515$. 